\title{
МОНГОЛ ЧОНОГОНО (JURINEA MONGOLICA Maxim.) УРГАМЛЫН ФИТОХИМИ БОЛОН БИОЛОГИЙН ИДЭВХИЙН СУДАЛГАА
}

\author{
М. Думаа ${ }^{1}$, Т. Солонго ${ }^{1}$, М. Болортуяа ${ }^{I}$, Г. Чүнсриймятав ${ }^{1,2}$, \\ Маргит Грүнер ${ }^{2}$, Д. Рэгдэл ${ }^{1}$, Ханс-Иаохим Кноелкер ${ }^{2}$ \\ ${ }^{l}$ Хими, химийн технологийн хүрээлэн, Шинэлэх ухааны Академи, Монгол улс \\ ${ }^{2}$ Хими технологийн тэнхим, Дрездений технологийн их сургууль, ХБНГУ \\ Цахим шуудан:duтаa_mishig@yahoo.com
}

Редакиид ирҮҮлсэн: 2016.02.15

Товч агуулга: Монгол чоногоно (Jurinea mongolica Maxim.) ургамлын газрын дээд хэсгийн этилацетатын бүлэг ханднаас хиспидулин бодисыг иээрээр ялгаж, түҮний молекульын бүтэи байгууламжийг масс спектрометр, ${ }^{1} \mathrm{H},{ }^{13} \mathrm{C}$ болон хоёр хэмжээст ияөмийн соронзон резонансын (ЦСР) спектроскопын аргаар таньж тодорхойлов. Тухайн ургамльнн нийлбэр алкалоид, хлороформ, этилацетатын хандны куарум сенсинг механизмыг дарангуйлах (quorum sensing (QS) system) идэвх нь 30 мг/мл тунд $10.0 \pm 0.0$ мм, $15.5 \pm 2.1$ мм, $12.0 \pm 4.24$ мм; хлороформын хандны Staphylococcus aureus (S. aureus), Micrococcus luteus (M. luteus), Staphylococcus epidermidis (S. epidermidis) бактерийн эсрэг идэвх нь 10 мг/мл тундаа 11.4 мм, 13.12 мм, 15.16 мм байв. Харин тухайн ургамльн мутагенийг дарангуйлах идэвх нь петролейны эфир, хлороформ, этилачетат, н-бутанол, усан үлдэгдэл болон нийлбэр алкалоидод 8\%, 62\%, 46\%, 7\%, 44\%, 59\% байв. М. чоногоно ургамльн метанолын хандньл

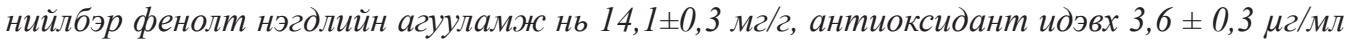
(ABTS), 1,3 $\pm 0,1$ нг/мл (DPPH) тус тус хэмжээтэй байв.

Түлхүур уг: Монгол чоногоно (Jurinea mongolica Maxim.), Сотроsitae, Хиспидулин, нийлбэр фенолт нэгдэл, куарум сенсинг механизм, бактерийн омог, мутаген, антиоксидант

\section{ОРШИЛ}

Монгол оронд Нийлмэл цэцэгтний (Compositae) овгийн 2 зүйл Чоногоно ургадаг. Арзгар жимст чоногоно (Jurinea chaetocarpa Ldb.), Монгол чоногоно (Jurinea mongolica Maxim.). Монгол чоногоно нь олон наст өвслөг ургамал, манай орны Их нууруудын хотгор (Хар-ус нуур), Олон нуур, Дорнод говь, Говь-Алтайн ургамал газар зүйн тойрогт цөл, цөлөрхөг хээрийн бүсэд уул толгодын чулуурхаг хажуу, элсэрхэг сайрын хөвөөгөөр ургадаг [1].
Одоогийн байдлаар дэлхий дээр Чоногоньl төрлийн 250 зүйл ургамал Төв болон Зүүн өмнөд Ази, Газрын дундад тэнгисийн орчмоор нилээд ихээр тархан ургана [2]. Түүнээс 19 зүйл Чоногоно зөвхөн Туркийн нутагт ургадаг ба тэдгээрийн 7 зүйл нь тухайн орны унаган ургамалд багтдаг $[3,4]$. Ер нь Чоногоны төрлийн ургамлын фитохими болон биологийн идэвхийн судалгаа бараг хийгдээгүй бөгөөд зөвхөн гурван зүйл Чоногоны газрын дээд 
хэсгээс сесквитерпены лактон [5-7], С-14, C-15 байрлал дээрээ хүчилтөрөгчтэй холбогдсон гермакранолид [8], таван цагирагт тритерпеныг ялгасан байдаг $[9,10]$. Туркийн эрдэмтэн С. Кирбаг, Ф. Зенгин Jurinea ancyrensis Bornm. ургамлын бактерийн эсрэг идэвхийг судалсан [11]. Энэтхэгийн ардын эмнэлэгт Jurinea dolomiae ургамлыг бэлгийн чадавх хийгээд дархлаа сайжруулахад хэрэглэдэг тухай мэдээлжээ [12]. Харин манай оронд ургадаг Монгол чоногоно ургамлын фитохимийн болон биологийн идэвхийн судалгаа огт хийгдээгүй байна.

Бид энэхүу бүтээлдээ манай орны унаган ургамлаар тодорхойлогдсон Монгол чоногоно (Jurinea mongolica Maxim.) ургамлын газрын дээд хэсгийн фитохимийн болон биологийн идэвхийн судалгааг хийхээр зорилго тавьж ажиллав.

\section{СУДАЛГААНЫ МАТЕРИАЛ БА АРГА ЗУЙ}

\section{Судалгааны материал}

Монгол чоногоно (Jurinea mongolica Maxim.) ургамлын газрын дээд хэсгийг 2014 оны 8 сард Дорноговь аймгийн Сайншанд сумын нутаг Ханбаянзүрх уулын хормой, элсэрхэг сайрын хөвөө, нүцгэн толгодоос түүж бэлтгэв. Тухайн ургамлын ангилал зүйн тодорхойлолтыг ШУА-ийн Ерөнхий болон сорилын биологийн хүрээлэнгийн проф., доктор Ч. Санчир хийв. Ургамлын хатаадас ШУА-ийн Хими, химийн технологийн хүрээлэнгийн Байгалийн нэгдлийн химийн лабораторид хадгалагдаж байна.

Арга зүй: Монгол чоногоно (Jurinea mongolica Maxim.) ургамлын газрын дээд хэсгийг түүж стандартын дагуу хатааж, нунтаглан бэлтгэв. Дээжийг 95\%-ийн этилийн спиртээр перколяцийн аргаар хандлав. Хандлагч уусмалыг зайлуулсны дараа өтгөн хандыг нэрмэл усаар сүспензлэн петролейны эфир, хлороформ, этилацетат, н-бутанолоор дараалуулан бүлэг ханд гарган авав. Бүлэг ханд бүрт нимгэн үеийн хроматографийн (HYX) судалгаа хийж, хэт ягаан туяаны (ХЯТ) гэрлээр шарж, илрүүлэгч урвалжаар тодруулан зохих дүн шинжилгээ хийв. Улмаар этилацетатын бүлэг хандыг баганат хроматографийн (БХ) аргаар төрөл бүрийн уусгагчийн системийг ашиглан Jm-1 бодисыг химийн цэвэр төлөв байдлаар ялган авч, түүний молекулын бүтэц байгууламжийг орчин үеийн спектроскопийн аргаар таньж тодорхойлов.

Тухайн ургамлын зарим бүлэг хандны куарум сенсинг механизмыг дарангуйлах идэвхийг (quorum sensing (QS) system) Ахмедийн [13], бактерийн эсрэг идэвхийг цаасан дискийн $[14,15]$, мутацийн эсрэг идэвхийг Амесийн сорилоор [1820], нийлбэр фенолт нэгдлийг Фолин - Чиколтье-ын [21], чөлөөт радикалыг дарангуйлах идэвхийг ABTS ба DPPH аргуудаар тус тус харьцуулан судлав [22, 23].

\section{СУДАЛГААНЫ АЖЛЫН ҮР ДҮН БА ХЭЛЭЛЦУҮЛЭГ}

\section{1. Монгол чоногоно (Jurinea mongolica} Maxim.) ургамлын фитохимийн судалгаа

Монгол чоногоно (Jurinea mongolica Maxim.) ургамлын газрын дээд хэсгийг түҮж агаар солилцох орчинд хатааж, гадны хольцоос цэвэрлэн бэлтгэв. ИйнхүҮ бэлтгэсэн дээжнээс 600 г-ыг жинлэн авч стандартын дагуу нунтаглаж, 2.7 л 95\%ийн этилийн спиртээр перколяцийн аргаар тасалгааны температурт 3 удаа хандалсан. Этилийн спиртийг нам даралтын дор вакуум ууршуулагчаар нэрж, 93.34 г өтгөн ханд гарган авав. Өтгөн хандыг нэрмэл усаар сүспензлэн петролейны эфир (5.07 г), хлороформ (1.91 г), этилацетат (2.23 г), н-бутанолоор (6.72 г) дараалан хандаллаа. Үлдэгдэл усан хандыг өтгөрүүлэв (29.96 г). Эдгээрээс этилацетатын хандыг БХ- 
ын аргаap Sephadex $L H-20$ маркийн адсорбентийг ашиглан $100 \%$ ус; $\mathrm{H}_{2} \mathrm{O}$ $\mathrm{CH}_{3} \mathrm{OH}$-ын 90\%-10\%-ын систем, $100 \%$ метанолоор дараалан угааж 55-62-р фракцаас Jm-1 (5.6 мг) бодисыг химийн цэвэр төлөв байдлаар ялгав. Jm-1 бодис нь шар өнгөтэй нунтаг бөгөөд метанолд сайн уусна, хлороформд уусахгүй. Тухайн бодисын масс нь ESI-MS m/z: $301.25[\mathrm{M}+\mathrm{H}]^{+}$ байсан ба түүний устөрөгчийн болон нүүрстөрөгчийн атомын тоо, тэдгээрийн харилцан үйлчлэлийг тогтоох зорилгоор түүнийг метанолд $\left(\mathrm{MeOD}_{3}\right)$ уусгаж Bruker Avance 600 МГц багаж дээр ${ }^{1} \mathrm{H}$ ПСР ба ${ }^{13} \mathrm{C}$, ЦСР-ын спектрыг бүртгэсэн дүнг 1-р хүснэгтэнд үзүүлэв.

Jm-1 бодисын ${ }^{1} \mathrm{H} \mathrm{ПСР} \mathrm{ба}{ }^{13} \mathrm{C} Ц С Р$-ын спектрын дүн, 600МГи, $\mathrm{MeOD}_{3}$

\begin{tabular}{|c|c|c|c|c|}
\hline № & Н-атом & $\begin{array}{c}\text { Химийн шилжилтын утга } \\
\text { (б c.х., мульт. чанар, ССХY Гц) }\end{array}$ & С-атом & $(\boldsymbol{\delta}$ c.x. $)$ \\
\hline 1 & - & - & - & - \\
\hline 2 & - & - & $\mathrm{C}-2$ & $166(\mathrm{C})$ \\
\hline 3 & $\mathrm{H}-3$ & $6.57(1 \mathrm{H}, \mathrm{s}, \mathrm{H}-3)$ & $\mathrm{C}-3$ & $103(\mathrm{CH})$ \\
\hline 4 & - & - & $\mathrm{C}-4$ & $183.5(\mathrm{C})$ \\
\hline 5 & $\mathrm{OH}$ & $13.01(1 \mathrm{H}, \mathrm{s})$ & C-5 & $164(\mathrm{C})$ \\
\hline 6 & - & - & $\mathrm{C}-6$ & $134.3(\mathrm{C})$ \\
\hline 7 & $\mathrm{OH}$ & - & $\mathrm{C}-7$ & $156(\mathrm{C})$ \\
\hline 8 & H-8 & $6.50(1 \mathrm{H}, \mathrm{s}, \mathrm{H}-8)$ & C-8 & $97(\mathrm{CH})$ \\
\hline 9 & - & - & C-9 & $154(\mathrm{C})$ \\
\hline 10 & - & - & $\mathrm{C}-10$ & $105(\mathrm{C})$ \\
\hline 1 ' & - & - & $\mathrm{C}-1$ & $124(\mathrm{C})$ \\
\hline $2^{\prime}$ & H-2' & $7.90(2 \mathrm{H}, \mathrm{d}, \mathrm{J}=8.6$ Гц, Н-2', Н-6’) & $\mathrm{C}-2^{\prime}$ & $129.2(\mathrm{CH})$ \\
\hline $3^{\prime}$ & H-3' & $6.95(2 \mathrm{H}, \mathrm{d}, \mathrm{J}=8.6$ Гц, H-3', H-5') & $\mathrm{C}-3^{\prime}$ & $117.5(\mathrm{CH})$ \\
\hline 4 ' & - & - & $\mathrm{C}-4$ & $162.5(\mathrm{C})$ \\
\hline 5 , & & - & $\mathrm{C}-5$ & $117.5(\mathrm{CH})$ \\
\hline $6^{\prime}$ & & - & $\mathrm{C}-6^{\prime}$ & $129.2(\mathrm{CH})$ \\
\hline 11 & $-\mathrm{CH}_{3}$ & $3.92\left(3 \mathrm{H}, \mathrm{s}, \mathrm{OCH}_{3}\right)$ & $-\mathrm{OCH}_{3}$ & 60.8 \\
\hline
\end{tabular}

${ }^{1} \mathrm{H}$ ПСР-ын спектрийн судалгааны дүнд $\delta 13.01$ - 3.92 саяны хэсгийн (с.х.) химийн шилжилтийн утганд нийтдээ 12 устөрөгчийн атомын сигнал илэрсэн. Эдгээр устөрөгчийн атомын сигналыг түүний мультиплет чанар, спин, спины харилцан үйлчлэлийн (CСXY) тогтмолыг харгалзан дүн шинжилгээ хийж, байрлалыг нь тогтоов.

$\begin{array}{lllllll}\delta & 6.57 & \text { ба } & \delta & 6.50 & \text { c.х.-ийн химийн }\end{array}$ шилжилтийн утганд тус бүр 1 протоны идэвхтэй 2 синглет сигнал илэрснийг H-3, Н-8 байрлалд, $\delta 7.90$ ба $\delta$ 6.95 c.х. -ийн химийн шилжилтийн утганд тус бүр 2 протоны идэвхтэй, 8.6 Гц-ийн ССХY-ийн тогтмолтой 2 дублет сигнал илэрснийг Н-2', Н-6' ба Н-3', Н-5' байрлалуудад тус тус оноосон. Харин $\delta 3.92$ с.Х.-ийн химийн шилжилтийн утганд 3 протоны идэвхтэй 1 синглет сигнал илэрснийг метоксил бүлэгт оноолоо. Ийнхүу ${ }^{1} \mathrm{H}$ ПСР-ын спектрийн судалгааны дүнд 1 метоксил бүлэг, 6 ароматик протон агуулсан нэгдэл байгааг урьдчилсан байдлаар тогтоов.

Цаашид тухайн бодисын нүүрстөрөгчийн атомын тоо тэдгээрийн халагдалтын зэргийг тогтоох зорилгоор ${ }^{13} \mathrm{C}$ 
ЦСР-ын спектрийг бүртгэхэд нийтдээ 16 нүүрстөрөгчийн атомын сигнал илэрсэн ба соронзон орны харьцангуй сул талбайд $\delta$ $183.5,166,164,134.3,156,154,162.5,124$, 105 с.х.-ийн хими шилжилтийн утганд 9 нүүрстөрөгчийн атомын сигнал өгөв. Харин соронзон орны харьцангуй хүчтэй талбайд $\delta 60.8$ c.Х.-т нэг сигнал илэрснийг метоксил бүлгийн нүүрстөрөгчийн атомд оноосон. $\delta 103,97,129.2$ ба 117.5 с.х.-т 4 сигнал илэрснийг метин бүлгийн нүүрстөрөгчийн атомуудад тус тус оноов.

Ийнхүу ${ }^{13} \mathrm{C}$ ЦСР-ын спектрийн судалгааны дүнгээс тухайн бодис нь нийт 16 нүүрстөрөгчийн атом агуулсан түүний 9 нүүрстөрөгчийн атом нь дөрөв халагдсан, нэг метоксил бүлэг агуулсан нэгдэл байх боломжтой гэж үзэв.

Улмаар Jm-1 бодисын устөрөгч болон нүүрстөрөгчийн атомуудын хамаарал, хэрхэн холбогдож байгааг тогтоох зорилгоор хоёр хэмжээст HSQC спектрийг бүртгэв. Тухайн спектрийн дүнд тус бүр нэг протоны идэвхтэй $\delta 103$ с.х. ба $\delta 97$ с.х-ийн хими шилжилтийн утгад 2 нүүрстөрөгчийн атомын сигнал илэрснийг Н-3 ба Н-8 байрлал дахь метин бүлгийн сигналтай, $\delta 60.80$ c.х.-ийн нүүрстөрөгчийн атомын сигналыг Н-11 байрлал дахь метоксил бүлэгт, харин $\delta 183.5$ с.х.-т илэрсэн 1 нүүрстөрөгчийн атомыг Н-4 байрлал дахь карбонил (СО) бүлэгт, $\delta$ 103, 97, 129.2, 117.5 с.х.-т байгаa 6 нүүрстөрөгчийн атомын сигналыг Н-3, Н-8, Н-2', Н-5', Н-3', Н-6' байрлал дахь устөрөгчийн атомуудтай тус тус холбоотой байгааг тогтоов. Харин $\delta 166,164,134.3$, $156,154,105,162.5,124$ с.х.-т бүртгэгдсэн 8 нүүрстөрөгчийн атомын сигналыг дөрөв халагдсан буюу ямарч устөрөгчийн атомтай холбоогүй болохыг батлав.

$\mathrm{Jm}-1$ бодисын устөрөгчийн атомууд нь хоёр, гурван холбооны дараах нүүрстөрөгчийн атомуудтай хэрхэн харицан үйлчлэлцсэн бүтэц байгууламжтай байгааг тогтоох зорилгоор хоёр хэмжээст НМВС спектрийг бүртгэж дүн шинжилгээ хийв. Энэхүү спектрийн дүнд ароматик муж дахь $\delta \mathrm{H}-3$ (1H, s) протон нь C-10, C-1', C-9; Н-8 $(1 \mathrm{H}, \mathrm{s})$ протон нь C-10, C-6, C-5; H-2' $(2 \mathrm{H}$, d, J=8.6 Гц) протон нь С-3', C-4', C-2; Н-6' $(2 \mathrm{H}, \mathrm{d}, J=8.6$ Гц) протон нь С-1', С-4', C-2; H-3' (2H, d, J=8.6 Гц) протон нь С-1', C-4' ба Н-5' (2H, d, J=8.6 Гц) протон нь С-4', C-3', C-1' нүүрстөрөгчийн атомуудтай, харин соронзон орны харьцангуй хүчтэй талбайд илэрсэн H-11 (3H, s) протон нь C-6, нүүрстөрөгчийн атомтай тус тус алсын харилцан үйлчлэлтэй байгааг 1-р зургаар үзҮҮлэв.

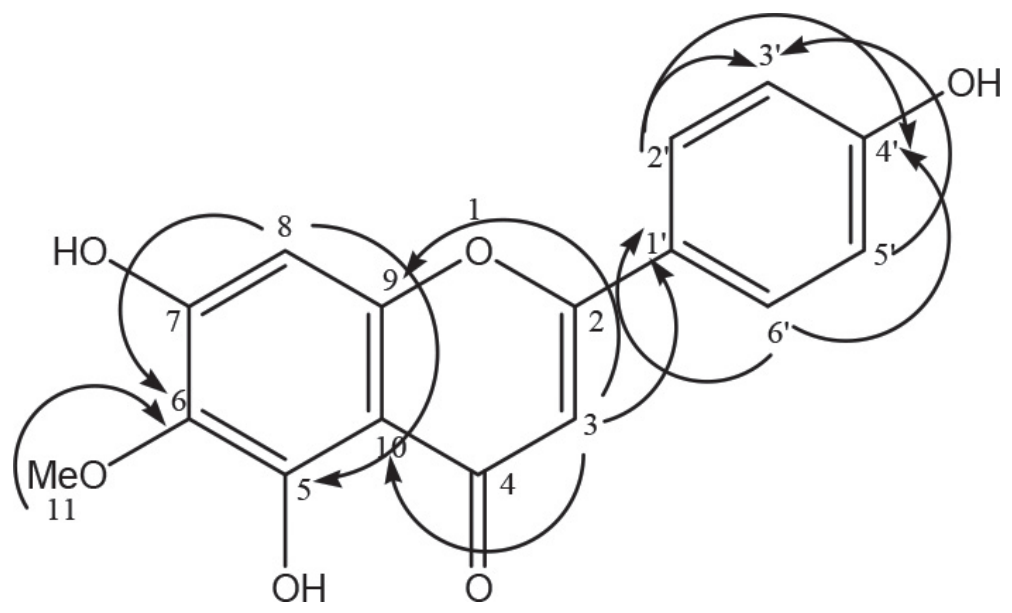

1-р зураг. Jm-1 бодисын 2D НМВС спектрын тайлал 
Ийнхүу бид “Jm-1" бодисын бүтэц байгууламжийг ${ }^{1} \mathrm{H} \Pi \mathrm{CP},{ }^{13} \mathrm{C}$ ба хоёр хэмжээст (HSQC, HMBC) ЦСР-ын спектроскопийн судалгааны дүнд нарийвчилсан тайлал хийж тухайн бодис нь $\mathrm{C}_{16} \mathrm{H}_{12} \mathrm{O}_{6}$ ерөнхий томёотой, 300.25 молекул масстай, флавоны бүлэгт хамрагдах зургаан ароматик протон, нэг метоксил, гурван гидроксил бүлэг агуулсан 5,7-дигидрокси-2-(4гидроксифенил)-6-метокси-4Н-хромен-4оне буюу Хиспидулин (Hispidulin) нэгдэл болохыг (2-р зураг) таньж тодорхойлов.<smiles>COc1c(O)cc2oc(-c3ccc(O)cc3)cc(=O)c2c1O</smiles>

2-р зураг. Хиспидулин (Hispidulin)

2. Куарум сенсинг механизмыг дарангуйлах идэвх (QS system)

Монгол чоногоно (Jurinea mongolica Maxim.) ургамлын газрын дээд хэсгийн зарим бүлэг ханд, усан үлдэгдэл болон нийлбэр алкалоидын куарум сенсинг механизмыг дарангуйлах идэвхийг Ахмедийн аргаар тодорхойлсон үр дүнг 2-р хүснэгтэнд үзүүлэв.

Монгол чоногоно ургамльн зарим бүлэг ханд, усан үлдэгдэл, нийлбэр алкалоидын

куарум сенсинг механизмыг дарангуйлах идэвх, мм

\begin{tabular}{|l|l|l|l|l|l|l|}
\hline № & Дээж & Тун & Үр дүн & Үр дүн & Дундаж \\
\hline Монгол чоногоно & 30 мг/мл & - & - & - \\
\hline 1 & Петролеиний эфирийн бүлэг ханд & 30 мг/мл & 14.0 & 17.0 & $15.5 \pm 2.12$ \\
\hline 2 & Хлороформын бүлэг ханд & 30 мг/мл & 9.0 & 15.0 & $12 \pm 4.24$ \\
\hline 3 & Этилацетатын бүлэг ханд & 30 мг/мл & - & - & - \\
\hline 4 & н-бутанолын бүлэг ханд & 30 мг/мл & - & - & - \\
\hline 5 & Усан үлдэгдэл & 30 мг/мл & 10.0 & 10.0 & $10 \pm 0.0$ \\
\hline 6 & Нийлбэр алкалоид & & & & \\
\hline
\end{tabular}

Судалгааны дүнд тухайн ургамлын петролейний эфир, н-бутанолын бүлэг ханд болон усан үлдэгдэл нь 30 мг/мл тундаа куарум сенсинг механизмыг дарангуйлах идэвх үзүүлээгүй байна. Харин хлороформ, этилацетатын бүлэг ханд болон нийлбэр алкалоид нь 30 мг/мл тундаa $15.5 \pm 2.12$ мм,
$12 \pm 4.24$ мм, $10 \pm 0.0$ мм тус тус хэмжээтэй куарум сенсинг механизмыг дарангуйлсан идэвх үзүүлэв. Тухайн судалгааны явцад микроорганизмын нягтаршил их байх тусам эс хоорондын харилцан үйлчлэл нэмэгдэн биофильм үүсгэдэг. Ийнхүу биофильм Үүссэнээр микроорганизмын 
эмэнд тэсвэртэй чанар нь нэмэгддэг ба энэ процессийг куарум сенсинг механизм зохицуулдаг байна. Өөрөөр хэлбэл куарум сенсинг механизмыг дарангуйлснаар микроорганизмын антибиотикт тэсвэртэй шинж чанарыг нь бууруулах боломжтой юм $[16,17]$.

\section{3. Бактерийн эсрэг идэвхийн судалгаа}

Монгол чоногоно ургамлын зарим бүлэг ханд, усан үлдэгдэл болон нийлбэр алкалоидын бактерийн эсрэг идэвхийн судалгааг 6 тест омгийг ашиглан, цаасан дискийн аргаар тодорхойлсон үр дүнг 3-p хүснэгтэнд үзүүлэв. А.В. Вауер нарын боловсруулсан бактерийн эсрэг идэвх тодорхойлдог цаасан дискийн арга нь микробиологийн судалгаанд өргөн хэрэглэдэг хялбар арга юм [14].

Монгол чоногоно ургамльн зарим бүлэг ханд, усан үлдэгдэл болон нийлбэр

3-р хүснэгт алкалоидын бактерийн эсрэг идэвх, мм

\begin{tabular}{|c|c|c|c|c|c|c|c|c|}
\hline № & Дээжийн нэр & Тун & $\begin{array}{c}P s . \\
\text { aeruginosa }\end{array}$ & E. coli & $\begin{array}{c}S . \\
\text { aureus }\end{array}$ & $\begin{array}{c}\text { M. } \\
\text { luteus }\end{array}$ & $\begin{array}{c}\text { E. faeca- } \\
\text { lus }\end{array}$ & $\begin{array}{c}S \text { epider- } \\
\text { midis }\end{array}$ \\
\hline \multicolumn{9}{|c|}{ Монгол чоногоно } \\
\hline 1 & Петролейний эфирийн бүлэг ханд & 10мг/мл & - & - & - & - & - & - \\
\hline 2 & Хлороформын бүлэг ханд & $10 \mathrm{Mг} / \mathrm{мл}$ & - & - & 11.4 & 13.12 & - & 15.16 \\
\hline 3 & Этилацетатын бүлэг ханд & $10 \mathrm{мг} / \mathrm{мл}$ & - & - & - & - & - & - \\
\hline 4 & н-бутанолын бүлэг ханд & $10 \mathrm{Mг} / \mathrm{Mл}$ & - & - & - & - & - & - \\
\hline 5 & Усан үлдэгдэл & $10 \mathrm{Mг} / \mathrm{Mл}$ & - & - & - & - & - & - \\
\hline \multirow[t]{2}{*}{6} & Нийлбэр алкалоид & $10 \mathrm{Mг} / \mathrm{мл}$ & - & - & 10.9 & 9.9 & - & - \\
\hline & Канамицин & & 14.12 & 14.14 & 18.17 & 15.16 & 16.17 & 19.20 \\
\hline
\end{tabular}
дискнь диаметер-8 мм

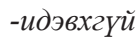

Судалгааны дүнгээс үзэхэд тухайн ургамлын петролейний эфир, этилацетат, н-бутанолын бүлэг ханд болон усан үлдэгдэл нь 10 мг/мл тундаa 6 омог бактерийн ургалтыг дарангуйлах идэвх үзүүлээгүй. Харин хлороформын бүлэг ханд 10 мг/мл тундаа PS. aeruginosa, E. faecalus, E. coli бактерын ургалтыг дарангуйлаагүй байсан бол $S$. aureus, $M$. luteus, $S$. epidermidis бактерын ургалтыг 11.4 мм, 13.12 мм, 15.16 мм тус тус хэмжээтэй дарангуйлсан идэвх Үзүүлсэн. Нийлбэр алкалоид нь 10 мг/мл тундаа Ps. aeruginosa, E. faecalus, E. coli,
$S$ epidermidis бактерын омгийн ургалтыг дарангуйлах идэвх үзүүлээгүй боловч, грам эерэг S. aureus, M. luteus бактерын ургалтыг 10.9 мм, 9.9 мм тус тус хэмжээтэй дарангуйлсан идэвх үзүүлэв.

\section{4. Мутагеныг дарангуйлах идэвхийн судалгаа}

Монгол чоногоно ургамлын зарим бүлэг ханд, усан үлдэгдэл, нийлбэр алкалоидын мутагеныг дарангуйлах идэвхийн судалгааг Амесийн сорилоор тодорхойлсон үр дүнг 4-р хүснэгтэнд үзүүлэв.

Монгол чоногоно ургамлын зарим бүлэг ханд, усан үлдэгдэл нийлбэр алкалоидын мутагеныг дарангуйлах идэвх, \%

\begin{tabular}{|c|c|c|c|c|c|c|}
\hline № & Дээю & Тун & $\begin{array}{l}\text { Колоны } \\
\text { тоо }\end{array}$ & $\begin{array}{l}\text { Колоны } \\
\text { тоо }\end{array}$ & $\begin{array}{l}\text { Дундаж } \\
\text { утга }\end{array}$ & $\begin{array}{l}\text { Дарангуйлах } \\
\text { идэвх \% }\end{array}$ \\
\hline \multicolumn{7}{|c|}{ Монгол чоногоно } \\
\hline 1 & Петролеиний эфирийн бүлэг ханд & $1 \mathrm{\mu \nu} / \mathrm{M} л$ & 250 & 204 & 227 & $8 \%$ \\
\hline 2 & Хлороформын бүлэг ханд & 1 мг/мл & 98 & - & - & $62 \%$ \\
\hline 3 & Этилацетатын бүлэг ханд & 1 мг/мл & 137 & - & - & $46 \%$ \\
\hline
\end{tabular}




\begin{tabular}{|l|l|l|l|l|l|l|}
\hline 4 & н-бутанолын бүлэг ханд & 1 мح/мл & 244 & 215 & 229.5 & $7 \%$ \\
\hline 5 & Усан үлдэгдэл & 1 мг/мл & 142 & - & - & $44 \%$ \\
\hline 6 & Нийлбэр алкалоид & 1 мг/мл & 105 & - & - & $59 \%$ \\
\hline 7 & Хяналт & & 251 & 246 & 248.5 & \\
\hline
\end{tabular}

-идэвхгүй

M. чоногоно ургамлын хлороформ, этилацетат, н-бутанолын бүлэг ханд, усан үлдэгдэл болон нийлбэр алкалоидын мутагеныг дарангуйлах идэвх нь 1 мг/ мл тундаа $62 \%, 46 \%, 44 \%, 59 \%$ тус тус хэмжээтэй буюу харьцангуй эерэг үр дүн үзүүлсэн. Харин петролейний эфир, н-бутанолын бүлэг хандны мутагеныг дарангуйлах идэвх нь тухайн тундаa $8 \%, 7 \%$ тус тус хэмжээтэй байгаа нь харьцангуй сул үр дүн үзүүлэв. Бидний ашигласан зарим төрлийн эм болон түүхий эдийн мутагеныг дарангуйлах идэвхийг тодорхойлдог Амесийн сорилын аргыг орчин үед нилээд өргөн хэрэглэдэг ба бактерийн эргэх мутацид үндэслэгддэг.

\section{5. Монгол чоногоно ургамлын метанолын хандны нийлбэр фенолт}

\section{нэгдэл ба антиоксидант идэвхийн судалгаа}

Монгол чоногоно ургамлын метанолын хандны нийлбэр фенолт нэгдлийг (НФН) Фолин - Чиколтье-ын аргаар тодорхойлоход $14.1 \pm 0.3$ мг/Г хэмжээтэй байв. Энэ аргын үндэслэл нь фенолт нэгдлүүд ФолинЧиколтье-ын шар уусмалыг шүлтийн орчинд ангижруулж гүн хөх өнгөтэй болгодогт оршино. Дараа нь өнгөт уусмалын гэрлийн шингээлтийг 765 нм долгионы уртад спектрофотометр багаж дээр хэмжиж, галлын хүчлийн стандарт муруйтай жишин тоон тодорхойлолт хийв.

Харин тухайн ургамлын метанолын хандны антиоксидант идэвхийг ABTS ба DPPH аргаар харьцуулан судалсан үр дүнг 5-р хүснэгтэнд үзүүлэв.

5-р хуснэгт

Монгол чоногоно ургамлын метанолын хандны антиоксидант идэвх, $\mu г / м л$

\begin{tabular}{|c|l|c|}
\hline № & Судалгааны үзүүлэлтүүд & Үр дүн \\
\hline 1 & Антиоксидант идэвх, (АВТS) & $3.6 \pm 0.3$ \\
\hline 2 & Антиоксидант идэвх, (DPPH) & $1.3 \pm 0.1$ \\
\hline
\end{tabular}

Тухайн ургамлын метанолын хандны чөлөөт радикалыг дарангуйлах идэвхийг ABTS ба DPPH аргаар харьцуулан судлахад $3.6 \pm 0.3 \mu г /$ мл (ABTS), $1.3 \pm 0.1 \mu г /$ мл(DPPH) тус тус хэмжээтэй байв. Судалгаанаас манай орны Монгол чоногоно (Jurinea mongolica Maxim.) ургамлын газрын дээд хэсгийн

метанолын хандны антиоксидант идэвхийг Пакистан улсын Jurinea dolomiaea Boiss. ургамлын үндэснээс гарган авсан төрөл бүрийн ханданд хийсэн үр дүнтэй жишиж үзэхэд харьцангуй өндөр идэвх үзүүлэв [24].

\section{ДҮГНЭЛТ}

Монгол чоногоно (Jurinea mongolica Maxim.) ургамлын газрын дээд хэсгийн этилацетатын бүлэг ханднаас Хиспидулин бодисыг химийн цэвэр төлөв байдлаар ялгаж түний молекулын бүтэц байгууламжийг ${ }^{1} \mathrm{H}$ ПСР, ${ }^{13} \mathrm{C}$ болон хоёр хэмжээст ЦСР-ын спектроскопын аргаар таньж тодорхойлов. Хиспидулин бодис нь тухайн зүйл ургамлаас анх удаа олдлоо.

M. чоногоно ургамлын газрын дээд хэсгийн зарим бүлэг ханд, усан үлдэгдэл болон нийлбэр алкалоидын куарум сенсинг механизмыг дарангуйлах идэвх, бактерийн эсрэг идэвх, мутагенийг дарангуйлах идэвх, 
чөлөөт радикалыг дарангуйлах идэвхийг тус тус судлав. Тухайн ургамлын метанолын хандны нийлбэр фенолт нэгдлийн агуулга нь $14.1 \pm 0.3$ мг/г байв. Энэ судалгааны дүнд манай орны M. чоногоно ургамлыг төрөл бүрийн эмийн түүхий эдээр ашиглах боломжтой гэж үзэв.

\section{Аиигласан бүтээлийн жагсаалт}

1. В.И.Грубов, Монгольин гуурст ургамлыг таних бичиг, Ган принт компани, УБ, 314, 2008.

2. H.Oztuk, U.Kolak, C.Meric, Antioxidant, Anticholinesterase and Antibacterial Activities of Jurinea consanguinea DC. Rec. Nat. Prod, 43-51. 2011.

3. A. Danin, P. H.Davis, Jurinea Cass. In flora of Turkey and the East Aegean Islands, Vol. 5, Davis PH (ed), University Press: Edinburg, 439-440 and 442-443, 1975.

4. B. Dogan, A. Duran, E. Martin, E.E.Hakki, Jurinea turcica (Asteraceae), a new species from North-West Anatolia, Turkey, Biologia 65, 28-32, 2010.

5. A.Rustaiyan, A.Nikneyad et al., Naturally occurring terpen derivatives. A guaianolide from Jurinea carduiformis, Phytochemistry 20, 1154, 1981.

6. M.Todorova, I.Ognyanov, Sesquiterpen lactones in leaves of Jurinea albicaulis, Planta Med. 50, 452-453, 1984.

7. S.K.Zakirov, S. Z. Kasymo, G.P.Sodyakin, Sesquiterpene lactones from Jurinea maxima, Kim, Prir. Soedin. 5, 656-657, 1975.

8. A. Rustaiyan, M. Ganji, Germacranolides from Jurinea eriobasis, Phytochemistry 27, 29912992, 1988.

9. K.L.Nikolajchak, C.R.Smith, Pentacyclic triterpenes of Jurinea anatolica and Jurinea consanguinea fruit, Lipids 2, 127-132, 1967.

10. M. Todorova, I.Ognyanov, Pentacyclic triterpenes in roots of J. albicaulis, Fitoterapia 67, 383, 1996.

11. S. Kirbag, F. Zengin, M. Kursat, Antimicribail activities of extracts of some plants Pak. J. Bot. 41, 2067-2070, 2009.

12. K.C.Sekar, S.K.Srivastava, New reports on aphrodisiac plants from Pin Valley National Park, Himachal Pradesh, Ethnobotany 17, 189-190, 2005.

13. I.Ahkmed, Z.Mehmood, F.Muhammad, Screening of some Indian medicinal plants for their antimicrobial properties. J. Ethnopharmocol 62, 183-193, 1998.

14. A.W.Bauer, W.M.M.Kirby et. al., Antibiotic susceptibility testing by a standardized single disk method, The American Journal of clinical Pathology, Vol. 45, 4, 493-496, 1966.

15. Perez, C., Pauli, M., Bazerque, P., An antibiotic assay by agar-well diffusion method. Acta Biologiae et Medicine Experimentalis , 15, 113-115, 1990.

16. K.H.McClean, M.K.Winson, L.Fish et al., Qourum sensing and Chromobacterium violaceum: exploitation of violaceim production of N-acylhomoserine lactones, Bicrobiology, 143 (Pt12), 3703-3711, 1997.

17. L.Hall-Stoodley, J.W.Costerton, P.Stoodley, "Bacterial biofilms: From the natural environment to infectious diseases". Nature Reviews Microbiology 2 (2): 95-108, 2004.

18. B.N.Ames, J.McCann, E.Yamasaki, Methods for detecting carcinogens with the Salmonella/ mammalian-microsome mutagenicity test. Mutation Research 31, 347-364, 1975.

19. S.Tejs, The Ames test: a methodological short review, Environmental biotechnology, 4 (1), 7-14, 2008.

20. B.Spellberg, J.H.Powers, E.P.Brass, L.G.Miller, J.E.Edwards, Trends in1286 antimicrobial drug development: implications for the future. Clin Infect Dis 38, 1279-1286, 2004.

21. V.Singleton, R.Orthofer, R.Lamuela-Raventos, Analysis of total phenols and other oxidation substrates and antioxidants by means of Folin-Ciocalteu reagent, Ed: Packer L, Oxidants and antioxidants, part A methods in enzimology, Vol 299, 152-178, 1999. Academic Press, New York. 
22. D.Martysiak-Zurowska, W.Wenta, A comparision of ABTS and DPPH methods for assessing the total antioxidant capacity of human milk, Acta Sci. Pol., Technol. Aliment. 11(1), 83-89, 2012.

23. M.Antolovich, P.D.Prenzler, E.Patsalides et al., Methods for testing antioxidant activity, School of Science and Technology, Charles Sturt University, Wagga, Australia, 2001.

24. N.Ali Shah, M.R.Khan, K.Naz, M.A.Khan, Antioxidant Potential, DNA Protection, and HPLC-DAD Analysis of Neglected Medicinal Jurinea dolomiaea Roots, BioMed Research International, Article ID 726241, 1-10, 2014. 


\title{
THE STUDY OF PHYTOCHEMICAL AND BIOLOGICAL ACTIVITY OF JURINEA MONGOLICA Maxim. GROWING IN MONGOLIA
}

\author{
M. Dumaa ${ }^{1}$, T. Solongo ${ }^{I}$, M. Bolortuya ${ }^{l}$, G. Chunsriimyatav ${ }^{1,2}$ \\ Margit Gruner ${ }^{2}$, D. Regdel', Hans-Jaochim Knoelker ${ }^{2}$ \\ ${ }^{\prime}$ Institute of Chemistry and Chemical Technology, MAS, Mongolia \\ 2 Department of Chemical Technology, Dresden University, Germany \\ e-mail:dumaa_mishig@yahoo.com
}

\begin{abstract}
Hispidulin was isolated from ethyl acetate fraction of aerial parts of Jurinea mongolica Maxim. growing in Mongolia for the first time. Its molecular structure was elucidated by using ${ }^{1} \mathrm{H},{ }^{13} \mathrm{C}$ and 2D NMR spectroscopic method.

In addition, anti-quorum sensing (QS) activity of the total alkaloids, chloroform and ethyl acetate fraction from aerial parts of $J$. mongolica were evaluated $10.0 \pm 0.0 \mathrm{MM}, 15.5 \pm 2.1 \mathrm{MM}$, $12.0 \pm 4.24 \mathrm{Mm}$ at $30 \mathrm{mg} / \mathrm{ml}$ dose; inhibition zone sizes against $S$. aureus, $M$. luteus, $S$. epidermidis strains of chloroformic fraction at $10 \mathrm{mg} / \mathrm{ml}$ dose were showed 11.4 мм, 13.12 мм, 15.16 мм, respectively.

Furthermore, anti-mutagenic activity of the petroleum ether, chloroform, ethyl acetate, n-buthanolic extract, water residue and total alkaloids from aerial parts of $J$. mongolica were evaluated $8 \%, 62 \%, 46 \%, 7 \%, 44 \%, 59 \%$, respectively. Total phenolic compounds of methanolic extract from aerial parts of $J$. mongolica was $14.1 \pm 0.3 \mathrm{mg} / \mathrm{g}$ and antioxidant activity were evaluated $3.6 \pm 0.3 \mu \mathrm{g} / \mathrm{ml}$ (ABTS) and $1.3 \pm 0.1 \mu \mathrm{g} / \mathrm{ml}$ (DPPH), respectively.
\end{abstract}

